\title{
ŞEKİL ŞARTINA UYULMADAN YAPILAN KEFALET SÖZLEŞMESINDE İFANIN SONUÇLARI
}

\author{
Dr. Hasan AYRANCI*
}

\section{KEFALET SÖZLEŞMESININ TANIMI VE ÖZELLIKLERİ}

Borçlar Kanununun 483'üncü maddesinde düzenlenen kefalet sözleşmesi, kefilin, alacakhya borcunu ödemeyen borçlunun bu borcu ifa etmemesinden şahsen sorumlu olacağına ilişkin taahhüdii olarak tanımlanmaktadır'. Şu halde öncelikle kefalet rızai bir sözleşmedir. Tarafların karşılıklı ve birbirine uygun irade beyanları ile kurulan kefalet sözleşmesinde kefil daima başkasına ait bir borcun yerine getirilmesini borçlanmaktadır.

Kefalet sözleşmesinin tarafları kefil ile alacaklıdır². Kefil ile alacakiı arasında kurulan bu sözleşmeye borçlu katılmamaktadır. Borçlunun rizasının alımmasına dahi ihtiyaç butunmamaktadır'. Borçlunun kefalet sözleşmesinden haberdar olması gerekli değildir. Hatta borçlu, bir kefalet

\footnotetext{
* Ankara Üniversitesi Hukuk Fakültesi Medeni Hukuk Anabilim Dalı

'Tobler, 14; Lerch/Tuason, 9; Müller. 77; Beck. Art.492, N.4; Anderegg. 8; Olgaç, 11; Giovanoli, Art 492, N.1; Reisoğlu. 1, 2: Tandoğan, 495; Hatemi/Serozan/Arpacı, 521; OR/Pestalozzi, Art.492, N.1; Grassinger, 13; Aral, 437: Yavuz, 762; Y.21.HD E.2000/2133 K.2000/2117 (YKD 2000, 933); Roma Hukukunda kefalet kurunu için bkz. Tahiroğlu, 323 $\mathrm{vd}$.

2 Lerch/Tuason, 39 vd;; Becker, Art.492, N.2; Beck, Art.492. N.70; Reisoğlu, 1; Giovanoli, Art.492, N.2. 52; Tandoğan. 495; Bucher, 287; OR/Pestalozzi, Art.492, N.1: Aral. 437; BGE 70 Il 273; Kefilin borçlunun kimliğinde yamılması esasłı bir hata hali oluşturur (Lerch/Tuason, 45); Kefalet sözleşmesi kefil i]e alacaklı arasında kurulmakla birikte alacaklı ile kefalet sözleşmesinin yápılmasında ilke olarak sadece asıl borçlunun yaran bukunduğu ve bu amaçla ủçüncỉ kişiyi kefalet sözleşmesi yapmaya sevkettiği unutulmamalıdır.

Becker. Art.492, N.2; Beck, Art.492, N.44; Giovanoli, Art.492, N.52; Bucher, 285; OR/Pestalozzi, Art.492, N.I: Aral. 437: Yavuz, 764: BGE 45 II 172; BGE 56 II l01 E.2: Asıl borçlunun iradesi kefaletin kurulmasında önem taşımaz. Asıl borçlu istemese bile ketalct sözleşmesi yapılabilir (Reisoğlu, Rücu, 473).
} 
sözleşmesinin yapılmasın istemeșe dahi sözleşme kurulabilir ve bu sözleşmenin hüküm ve sonuç doğurması borçlunun iradesine bağlı olmaz Ancak bu durum kefalet lehtarının kefalet sözleşmesinden etkilenmeyeceği anlamına gelmemektedir. Asıl borçlunun borcunu yerine getirmemesi ve kefilin kefalet sözleşmesinden doğan borcunu yerine getirmesi halinde, kefil, alacağa kanuni halef olmaktadır ${ }^{4}$.

Kefalet sözleşmesinin amacı alacaklının alacağını şahsen teminat altına almaktır'.

Kefalet sözleşmesinin geçerliliği, geçerli bir asıl borcun varlığını gerektirir (BK m.485). Zira kefalet sözleşmesi feri bir sözleşmedir ${ }^{6}$. Bu özellik, kefilin borcunun doğuşu, varlığını devam ettirmesi ve sona ermesi bakımından asıl borcun varlığına baglı olmasını gerektirir. Kefaletin tali özelliği ise adi kefalette alacaklının asıl borçluya karşı takip yapıp da bu takip semeresiz kalmadıç̧a kefile başvuramamasını ifade etmektedir?

Kefalet konusu borç, sözleşmeden doğan bir borç olabileceğgi gibi herhangi bir sebepten doğan bir borç da olabilir. Kefalet sözleşmesinde kefilin borcu her zaman için para cinsinden ifade edilir. Bu miktar, alacaklının sözleşmenin yerine getirilmesine ilişkin olan menfaatinin yani müspet zararının karşılığ olarak değerlendirilmektedir ${ }^{\star}$.

Kefalet sözleşmesi ilke olarak tek tarafa borç yükleyen sözleşmelerdendir. Çïnkü kefil, bir karşı edim ilişkisine girmeden borç altına girmektedir'.

*Yavuz, 764; Olgaç, 40; Kefil jle borçlu arasında kefalet sözleşmesi nedeniyle herhangi bir hukuki ilişki bulunmayabilir. Ancak kefill kefalet borcunu ödediğinde kanundan doğan bir hukuki ilişki söz konusu olur (Bucher, 287).

s Beck, Art.492. N.4, 5; Giovanoli, Art.492, Hatemi/Serozan/Arpaci, 521; Y 21.HD E.2000/2133 K.2000/2117 (YKD 2000, 933).

${ }^{6}$ Oser, 860; von Tuhr, 226; Tobler, 13 vd.; Lerch/Tuason, 9; Rein, 33, 52 vd;; Müller, 77; Becker, Art.492, N.22; Beck, Art.492, N.88; von Büren, 350; Tekinay. Müteselsil. 746; Tahiroğlu, 332; Giovanoli, Art.492, N.2; Olgaç. 12; Schwenzer, 438; Bucher, 287-288; Reisoğtu, 2-3; Tandoğan, 497; Hatemi/Serozan/Arpacı, 522; Grassinger, 13, 17; OR/Pestalozzi, Art.492, N.13; Aral, 438; BGE 101 II 323 E.1; BGE 113 II 437 E.b; Bu özellik kefalet sözleşmeșini garanti sözleşmesinden ayırmaktadır. Kefaletin feri niteliginden dolayı kefalet borcunun muaccel olması İsviçre Hukukunda Türk Hukukundan farklı olarak asıl borcun muaccel olmasına bağlıdır. Buna karşılık BK m.49l/1l'de OR'nin eski düzendenmesise uygun olarak kefalet borcunun muacceliyeti için ihtar ફ̧artı aranmaktadir (von Tubr, Schluss, 246).

${ }^{7}$ Gjovanoli, Art 492. N.2; Grassinger, I4; von Büren, 350; Aral, 441.

${ }^{8}$ Yavuz, 765 .

"Bankaların verdiǧi kefalette ise kural olarak ücret alınmaktadır (Bucher. 287). Borçlunun kimliği ivazlı kefalet sözleşmelerinde de önem taşımaktadır (Becker, Art.492, N.13). 


\section{KEFALET SÖZLEŞMESİNİN GEÇERLİLİK ŞARTLARI}

\section{A. Geçerli Bir Asıl Borcun Bulunması}

Kefalet sözleşmesinin geçerli olmasının ilk şartı geçerli bir borcun bulunmasıdır (BK m.485) ${ }^{10}$. Bu şart, kefalet sözleşmesinin feri niteliğinden kaynaklanmaktadır. Geçersiz veya olmayan bir borca kefil olunmuşsa kefalet borcundan söz edilemez. Buna karşılık gelecekte dogacak bir borç veya şarta bağlı bir borç için kefalet sözleşmesi yapılabilir (BK m.485). Bu husus özellikle kira sözleşmelerinde henüz doğmamış kira parasına kefalet ile kredi veya kredi kartı sözleşmelerinde gelecekte kullanılacak kredi miktarına ilişkin kefalette büyük önem arz etmektedir. Bu tür kefalet sözleşmelerinde şekil şartına ve özellikle kefilin sorumlu olduğu meblağın belirli olmasına ilişkin şekil şartına riayet etmek gerekmektedir".

Kefalet sözleşmesinin geçerli olması aynı zamanda asıl borcun belirli veya belirlenebilir olmasma da baglıdır ${ }^{2}$. Ancak asıl borcun mutlaka bir para borcu olması gerekli degildir. Bir verme borcu veya şahsa bağlı borç kefalet sözleşmesine konu olabilir. Ancak bu durumda para ile ölçülebilen bir edimin bulunması gereklidir ${ }^{13}$.

\section{B. Kefalet Sözleşmeşinin Geçerli Olarak Kurulması}

Kefalet sözleşmesinin diğer sözleşmeler için de söz konusu olan sinırlara uygun olarak yapılması gereklidir. Bu anlamda hukuka, ahlaka aykırı olmaması; imkansız olmaması, sözleşme taraflarının gerekli ehliyeti taşıması gibi başlıklar sayılabilir. Kefilin MK m.23/II anlamında kendini ekonomik zorluģa dusşürecek kefalet sözleşmesi yapması butlan sonucu doğurmaz ${ }^{14}$.

Alacaklı ve kefilin karşıllkklı ve birbirine uygun icap ve kabulü ile kefalet sözleşmesi kurulur. Kefalet sözleşmesinin temsil yoluyla da kurulması mümkündür ${ }^{15}$.

"'Beck, Art.492, N.107; Anderegg. 12; Giovanoli, Art.492, N.68: Tandoğan. 520; Tandoğan, Geçerlitik, 19; Aral, 445; Tobter, 17. Yazar bu hïkmün aslında gereksiz olduğunu, kefalet sözleşmesinin kanunda bulunan tanımından anlaşıldığını ifade etmektedir.

"Giovanoli. Art.492, N.69: bkz. von Tuhr, 225.

${ }^{12}$ Beck. Art 492, N.107. Art.493, N.9; Rein, 33; Giovanoli, An.492, N.4. 72; Reisołtu, 11; Tandoğan, 550-551; Tandoğan, Geçerlilik, 45-46; Hatemi/Serozan/Arpac1, 524; OR/Pestalozzi. Art.492, N.12; Grassinger, 101; Aral, 453-454; BGE 128 Ill 434.

${ }^{13}$ Beck, Art 492, N.10: OR/Pestalozzi, Art.492, N.17.

it OR/Pestalozzi, Art 492, N.21. Zira kişiliŏin korunmas itkesi ekonomik gücünden fazla yük getirecek işlemler yapma yasağı getirmemektedir. Aynı şekilde bkz. BGE 95 Il 57.

15 Oser. 858; Lerch/Tuason, 43; Becker. Art.492, N.2; Rein, 32; Beck, Art.492, N.27; Anderegg. 26-27; Giovanoli. Art.492, N.56. Art.493, N.47 vd.; Reisoğlu, 40; Tandoğan, 


\section{C. Şekil Şartına Uyulması}

\section{Genel Olarak}

Borçlar Kanunun 484'üncü maddesi kefalet sözleşmesinin geçerliliğini yazılı şekil şartına ve kefilin sorumlu olduğu miktarın belirlenmesine bağlamaktadır. Aslında BK 484 'te sözì edilen şekil şartı BK m.1l'de bulunan şekil şartımın tekrarından ibarettir ${ }^{16}$.

\section{Yazll Şekil Şartı}

Kefalet sözleşmesinde şekil serbestisi düşüncesi 19.Yüzyılın başlarında hakim olmuş ancak daha sonra şekil şartı öngörülmüştür. Bu gelişmelerle birlikte ilk olarak kefilin korunması ve ikinci olarak da şekil kurallarına gereksiz ölçüde önem vermenin yarattığı sorunlar tartışma konularını oluşturmuştur ${ }^{17}$.

Kefalet sözleşmesi ancak yazılı şekil şartma uymakla geçerli olarak kurulabilir (BK m.484, m.11/II 2 vd.). Kefalet sözleşmelerinde aranan bu şekil şartı, ispat şartı deģil geçerlilik şartıdır' ${ }^{18}$.

Kefalet sözleşmesinde şekil şartı hukuki güvenliğe kısmen hizmet eder ${ }^{19}$. Onun asıl amacı kefili korumaktır. Düzenlemenin amac1 ispat kolaylığı săğlanak veya alacaklının korunması değildir. Kefil, kefalet sözleşmesine ilişkin irade beyanında bulunurken çoğu zaman

538-539; Tăndoğan, Geçerlilik, 35; Grassinger, I19 vd: OR/Pestalozzi. Art.492. N.2; Aral. 450-451. Bu temsil yetkisi genel vekâletname ile değil özel vekâletname ile verilebilir.

1" Roma Hukukunda kefalet sözlü sózleşme ile yapılsyordu. En eski sözlü kefalet sözleşmesi sponsio dur. Sonraki zamantarda fideprontisso ve modern hukuku da etkileyen fideitussio adlarında kefalet sózleşmeleri yapıldo (Tahiroğlu. 325).

${ }^{17}$ Bkz.Rein, 29. 1881 yılında yapılan İsviçrc Borçlar Kanunu (OR) kefalet sórleşmesindc şekil şartını ongörmüştü.

${ }^{10}$ Reichel, 173, 178; von Tuhr, 225; Tobler, 8; Lerch/Tuason, 36; Becker. Art.493. N.7; Frey, 45; Müller, 78. 80; Beck. Art 493. Nr.15; Anderegg. 8. 57; Gigcr. 62: Bitge. 370; Tandoğ̣an. Geçerlilik, 38; Reisoğlu. 43, 44; Oser/Schönenberger, Art.493. N.45; Giovanoli,

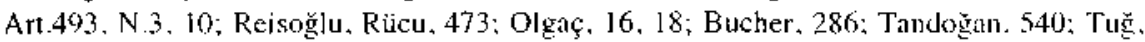
107; Reisoğlu. Muteberlik, 373; Wacke. 17, 19; Giger, 62; Tu是, 107: OR/Pestalozzi, Art.493, N.3, 6: Grassinger, 98; Aral. 45I: Y IBK 12.04.1944, 14/13; Y.21.HD E.2000/2133 K.2000/2117 (YKD 2000. 933); Y.19.HD E.1999/1901 K.1999/2434 (YKD 1999. 1426. 1427); Y.11.HD E.2002/630 K.2002/4497 (YKD 2002. 1813); Y.19.HD E.2000/6362 K.2001/234 (YKD 2002, 425); BGE 42 II E.3; BGE 119 IA 44I E.2. Fransi\% ve Italyan Hukukunda ispat şckli olarak öngörülmüştür (Becker. Art.493. N.7: Rein. 29): Roma Hukukunda sözlï olarak yapılan kefalet türü olan Fideiussio da alacakil fideiussor ’arın ödeme güçleri konusunda şüphesi varsa formula verilmesini isteyebilirdi (Tahiroğlu.. 233).

"Beck. Art 493. N.I ve N.8. 
sorumluluğunun ağılığmı ve bu beyanın sonuçlarımı tam olarak düşünmez. Zira sorumluluk hemen doğmayacağı gibi asıl borçlunun borcu ifa etmemesi gibi bir şartın gerçekleşmesine de bağlıdır. O halde kefil düşünmeden hareket etmekten, çoğu zaman karşılıksız olan kendi iyiniyetinden ve sonunu hesaplamadığı hareketlerden korunmalıdır. Bu haliyle tek taraflı olarak borç altına giren kefilin daha iyi düşünmesi sağlanmış ve tedbirli hareket etmesine yol açılmıştır. Böylece kefil, düşünmeden hareket etmeyecek aceleci davranmaktan korunacaktır ${ }^{20}$.

Kefalet sözleşmesinin şekle tabi olması emredici bir kanun hükmüne dayanabilir" ${ }^{21}$. Şekil şartım düzenleyen hükmün emredici olması kefalet sözleşmesinde gerekli asgari şartların bulunması zorunluluğunu ifade

2) Reichel, 173, 178; Tobler, 8, 13; Rein. 29; Müller. 79. Becker, Art.493, N.1; Beck. Art.493. N.8; Frey, 37; Merz, N.472; Reisoglu, Muteberlik, 373; Olgaç, 16; Yavuz, 773; Reisoğlu, 43; Tuğ. 107; Giger, 63; Tandoğan. 540: Tandoğan, Geçerlilik, 37; Tuğ, 107-108: Hatemi/Serozan/Arpac1. 522; Grassinger, 98; Schwenzer, 193-194; OR/Pestalozzi, Ant.493, N.I; Aral, 45]; Altaş, 66; BGE 111 II 175 E.3; BGE 84 I 119 E.3; BGE 93 II 383 ff.: BGE 44 II 61 E.3: BGE 42 II 149 E.3; II 9 IA 441 E.2 c: BGE 93 Il 379 E.4 b: Y IBK 12.04.1944, 14/13; BGE 9311383 E.b; Lerch/Tuason, 38. Yazara göre kanun koyucunun şekil şartın koymasındaki amacı kefitin düşüncesizcc borçlandırıcı işlem yapmasını engellemektit. Yoksa onu ifadan korumak gibi bir amacı bulunmamaktadır (Aynı şekilde bkz. Reichel, 178-179). Bu görüşe katılmıyoruz: jsviçre Borçlar Kanunun (OR) kefalete iliş̧in şekil hükümleri kefili daha iyi korumak amacıyla geliştirilmiş̧tir (BGE 81 II 64 E.1). Ekonomik krizle birlikte kefalet kurumu çok kötü sonuçlara yol açmış çoğu kez kefilin aciz haline düşmesine yol açılmıştır. İsviçre Hukukunda şekil şartı ile sağlanmak istenen kefïlin korunması amacının Türk Hukukunda halen var olan düzenlemelerle săglanamadığına inanılmıştı. Kefilin sadece yazılı şekil şartı ile sonuçlarını düşünmeden iyiniyetli hareket tarzından. menfaati olmadığ halde gereksiz ve ekonomik mahvına sebep olabilecek yuik altına girmesinden uzak tutulamadı̆̆ı görülmüş kısaca kefil, yazılı şekil şartı ile temkinli hareket etmesi sağlanamadığından yeni bazı düzenlemelerin getirilmesi zorunluluğu ortaya çıkmıştı. Bu amacın gerçekleştirilmesi için daha ağır şekil şartları OR $493^{\circ} \mathrm{e}$ konulmuştur (Anderegg, 4). Bu çalışmaların sonucunda OR 493 yedi fıkra halinde yeniden düzenienniştir. Yeni düzenleme pek çok şekil kuralı gettirmektedir. Bu anlamda olmak üzere gerçek kişilerin 2000 İsviçre Franğ üzerinde bulunan kefalet miktarı için resmi şekil şartı getirildiŏini örnck olarak gösterebiliriz; Kefalet sözleşmesinde şeklin kısmen hukuki güvenliğe hizmet ettiği astl fonksiyonunun ise kefili korumak olduğu göruişü için bkz. Beck. Art.493. N.1; Federal Mahkeme milletler arası özcl hukuk bakınından kefalet sözleşmesine iliş̧kin şekil hükümlerini kamu düzeninden saymıştır (BGE 93 II 376 E.4); Alman Hukukunda da şekil hükmünün amacı aynı şekilde değerlendirilmektedir (Larenz. Besonderer, 42 1): Kefalet hükümleri kefili o kadar güçlü bir korumá altına almıştır ki bazı yazarlar alacaklı lehine olarak kefalel yerine müteselsil borcu önermektedir (bkz. Tekinay. Müteselsil, 746r.

$\therefore$ Beck. Art.493, Nr.13; Giovanoli, Art.493, N.10a; OR/Pestalozzi, Art.493. N: 1; BGE 93 II 379 E.4 a: BGE 84 [ 1]9 E.3. 
etmektedir ${ }^{22}$. Ancak bu hüküm kamu düzenine (ordre public) ilişkin değildir ${ }^{23}$.

Kefilin korunması amacı kefalet sözleşmesinde önemli olan tüm unsurların diğer bir ifade ile sözleşmenin esaslı noktalarının şekil şartına tabi olmasını zorunlu $\mathrm{k}_{1} \mathrm{ar}^{24}$. Su halde kefalet beyanında ilke olarak borçlu, alacaklı, sorumluluk miktarı ve kefalet altına alınan asıl borç bulunmalıdır ${ }^{25}$.

Alacaklının ismen belirtilmesi gerekli değildir ${ }^{26}$. Ancak borçlunun şahsı ismen zikredilmelidir. Zira bu kişinin kim olduğu kefilin sorumluluğunun doğması bakımından önemlidir. Nitekim asıl borçlunun borçłarını yerine getirmeme alışkanlığı bulunan bir kişi olması halinde kefil daha büyilk bir riziko altında bulunacaktır ${ }^{27}$. Asıl borç miktarının yazılı şekilde belirtilmesi şartı bulunmamaktadır. Çünkü kefilin sorumlu olduğu miktarın belirtilmesi yeterli sayılmıştır ${ }^{28}$.

Borçlar Kanunun 484'üncỉ maddesi kefalet beyanında bulunması gereken asgari unsurları belirtmiştir. Bu unsurlar dışında tarafların kararlaştırdıkları yan noktalar ancak kefilin durumunu ağırlaştırıyorsa şekle tabidir. Buna karşıllkk kefilin durumunu hafifleten sorumluluk miktarının azaltılması, müteselsil kefaletin adi kefalete dönüştürülmesi, kefaletin

${ }^{22}$ Beck. Art 493 , Nr.13.

${ }^{23}$ Reisoğlu, Muteberlik, 376; Giovanoli, Art.493. N.10a; Tandoğan, 540; OR/Pestalozzi, Art.493, N.1; Reisoğlu, 46; BGE 11111175 E.3; BGE 84 I 119 E.3; Yargıtay eski bir karannda şekljn kamu düzenine ilişkin oldugunu ifade etmiştir Y 4.HD 20.04.1957 2318 (Reisoğlu, 46, dn.198'den naklen); Grassinger, 98. Kefalet sözleşmesinde şekil şartının kamu düzeninden olmadığı İsviçre Borçlar Kanunun 1939 tarihli gerekçesinde (s.850) açıkça belìtilmiştir (Aynı yer dn.129'dan naklen); 110 II 484 E.1; Milletlerarası özel hukuk bakımından bk2. BGE 93 II 379 E.4 a. Milletler arası özel hukuk ve uygulanacak hukuk bakımından kefaletin şekle tabi tutulması ile kefil yanında ailesinin de zaruret haline düşmesini engelleme amacı bulunabileceği ve bu nedenle kamu düzeni ile ilgi kurulabileceği görüşünün değerlendirilmesi için bkz. aynı yer. Pestalozzi de aynı konuya sosyal amaç bakımından yaklaşmaktadır (OR/Pestalozzi, Art.493, N.1).

${ }^{24}$ Lerch/Tuason. 36; Rein, 31; Müller, 78-79; Beck, Art 493. Nr.8; Anderegg, 7. 15; Giovanoli. Art.493, N.15; Giger, 62; Tandoğan, Geçerlitik, 42; Tuğ, 45; Grassinger, 101; Merz. Vertrag, 173; BGE I19 IA 441 E.2.

${ }^{25}$ Beck. Att 493, Nr.8; Becker, Art.493 N.2; BGE 46 II 97 E.2.

${ }^{2 \hbar}$ Lerch/Tuason, 42; Becker, Art.493, N.4; Rein. 33; Anderegg, 12; Olgaç, 17; Tandoğan, 550; Tandoğan. Geçerlilik, 45; Tuğ, 108; Giovanoli, Art.493. N.15; Aral, 453; Grassinger. 103: bkz. Tobler, 11; BGE 46 Il $97 \mathrm{f}$ :: Beck. Art.493. Nr.8. Kefalet gelecekte meydana gelen bir alacak için de verilebilir. Ayrıca alacaklının şahsı kefił için önemli deg̣ildir. Bu nedenlc alacaklının kimliğinin şekil şartına tabi beyanda bulunması gerekmemektedir (Beck, Art 493, Nr.36-37).

27 Beck. Art.493. Nr.8; Giger, 127; Reisoğlu. 52; Aral, 453; Tandoğan, 552; Tandoğan. Geçerlilik, 45; Tuğ. 408; Anderegg, 13 (Yazar borçlunun belirlenebilir olmasını yeterli saymaktadır); Alman Hukuku bakımından Larenz., 89, 610.

${ }^{2 \times}$ Beck, Art 493 . Nr.9. 
zamanaşımına bağlanması veya kefaletin şarta bağlanması gibi her türlü yan anlaşma şekle tabi olmadan geçerlidir ${ }^{29}$.

Yazılı beyanda kefil, kefalet gibi sözcüklerin yer alması zorúnlu değildir. Ancak kişinin kefalet amacı ile sözleşmeye imza attığı açıķ̧a anlaşıımalıdır. Borcu doğuran yazılı sözleşmenin altında bulunan yalın bir başka imza kefalet sonucu doğurmaz ${ }^{30}$. Kefalet sözleşmesinin tamamının veya sözleşmenin kefalet sözleşmesi olduğuna ilişkin kelimenin yabancı bir dilde ifade edilmesi mümkündür ${ }^{3 \prime}$. Ancak bu durumda kefillin bu sözcügüün anlamını bilip bilmediği, bilmiyorsa hata veya hile nedeniyle sözleşmenin geçersiz olabilecegini degerlendirmek gerekir.

Kefalet beyanında tarihin bulunması şartı aranmamaktadır ${ }^{32}$.

Kefalet sözleşmesi en azından adi yazılı şekilde yapılmalıdır. Kefalet beyanının altının kefil tarafından imzalanmıs olması yeterlidir (BK $\mathrm{m} .13$ ). Zira, Şekil şartı sadece borç altına giren kefilin irade beyanı için gereklidir" ${ }^{33}$. Ayrıca alacaklının sözleşmeye ilişkin beyanının yazılı şekle uyması gerekli değ ildir $^{34}$. Alacaklının sözlü kabul beyanında bulunmaș veya zımnen kabul beyanında bulunması yeterlidir ${ }^{35}$.

Taraflar kefalet sözleşmesinin geçerliliģini noterde imzaların tasdiki gibi daha ağır bir şekil şartına tabi olmasını kararlaştırabilirler ${ }^{3 / 6}$.

${ }^{2 y}$ Tobler, 11, 12-13; Lerch/Tuason. 37; Becker, Art.493, N.5; Rein, 34; Beck, Art.493, Nr.l1, 79; Anderegg, 1, 7, 15; Giovanoli, Art.493, N.17; Tandoğan, 549; Tandoğan. Geçerlilik, 43; Grassinger, 111; BGE 44 II 63 E.3; BGE 50 II 249; ; BGE 119 IA 441 E.2 c; bkz. Y.19.HD E.2000/6362 K.2001/234 (YKD 2002, 425).

31. Tobler, 11-12; Lerch/Tuason, 36; Rein, 31: Anderegg, 8: Giovanoli, Art.492, N.4; Olgaç. 16; Tandoğan, Geçerlilik, 40; Reisoğlu, Muteberlik, 377; Reisoğlu, 47; Grassinger. 103; OR/Pestalozzi, Art.492, N.3.

${ }^{3 \prime B e c k, ~ A r t .473, ~ N .26 ; ~ W a c k e, 17 ; ~ A n c a k ~ Y a r g ı t a y ~} 805$ sayılı Kanunun 4'üncü maddesine dayanarak kefalet sözleşmesinin Türkçe yapılmasının geçerlilik şartı olduğunu belirtmektedir (Y 11.HD E.1979/3309 K.1979/5469 YKD 1980, 388 vd.).

${ }^{32}$ Beck, Art.493, Nr.8; Giovanoli, Art.493, N.17; Tandoğan, Geçerlilik, 40.

${ }^{33}$ Oser, 859; Múller, 78-79; Schönenberger/Jäggi, Art.13. N.77; Bilge. 371; Bucher, 29I; Aral, 451: Altaş. 50-51; Furrer, 32. Yazar sözleşmenin karşı tarafının imzalamakla yükü̈mlü olmadığı kanuni şekle tek taraflı şekil hükümleri adını vermektedir. Aynı şekilde bkz. Gauch/Schuep/Jäggi, N.506 ve OR/Pestalozzi. Art.493, N.2; 1881 tarihli İsviçre Borçlar Kanununun (OR) 491'nci maddesi kefalet sózleşmesinin şekle tabi olduğunu belirtirken (der schriftlichen Vertragsform) 1911 tarihli mehaz OR 493 'üncü maddesinde kefilin beyanının yazılı olması şartını (schriftlichen Erklärung des Bürgen) aramaktadır.

${ }^{H}$ Oser, 859; Tobler, 12; Anderegg, 8. 9; Bilge, 371; Giovanoli, Art.493, N.9; Grassinger. 98; Olgaç, 16; Tuğ, 108; Yavuz. 773; Beck, Art.493, N.7, 13. Zira şekil şartı sadece kefili korumay! amaçlamaktadır (ayn yer N.13).

${ }^{35}$ Tobler, 12; Beck, Art.493, Nr.13; Becker, Art.493, N.6 ve Art.492 N.10; Rein. 43; Anderegg, 9; Giovanoli, Art.492. N.53; Bucher. 29I; OR/Pestalozzi, Art.492. N.3.

${ }^{36}$ Beck, Art.493, N.14. 
Yazılı geçerlilik şartı kefaletin tüm türleri için uyulması gereken bir şarttır. Birlikte kefalet. kısmi kefalet, kefile kefalet gibi her kefalet türünde uyulması geçerlilik şartıdır. Müteselsil kefalet söz konusu ise bunun da yazılı şekil şătı kapsammda yer alması getekmektedir (BK m.487/Il $)^{37}$.

Kefalet sözleşmesinin yazılı şekilde yapılması zorunluluğ yazılı belgenin kaybolması halinde sözleşmenin geçerli kalmaya devam etmesi sonucunu doğ̆urur. Usul hukuku hükümleri saklıdır ${ }^{38}$.

\section{Kefilin Sorumlu Olduğu Miktarn Belirtilmesi}

Kefalet sözleşmesinde kefalet miktarının belirtilmesi yazılı şekil şartının muhtevası içinde yer almalıdır ${ }^{39}$. Bunun muhteva içinde bulunmaması kefalet sözleşmesinin geçersiz olması sonucunu doğurur ${ }^{-11}$.

Sorunluluk miktarının sınırlı olması 1911 tarihli mehaz İsviçre Borçlar Kanunu revizyonunda getirilmiştir. Bu düzenlemeden önce önceden sorumluluk smirının belirlenebilir olması yeterli sayılmaktaydı.

Kefalet senedinde kefilin sorumlu olduğu azami miktar yazılmış olmalıdır ${ }^{.1}$. Böylece kefilin sorumluluğunun kapsamı açık bir şekilde belirlenmiş olur.

Kefïlin sorumlu olduğu miktar para cinsinden belirlenmelidir ${ }^{42}$. Ancak kefalet miktarının ülke parası cinsinden belirtilmesi gerekli değildit ${ }^{43}$.

\section{4. Şekil Şartına Uymamanin Sonuçlan}

Geçerlilik şartına uyulmadan yapılan kefalet sôzleşmesi geçerli olmaz (BK m.11//I) ${ }^{+4}$. Borçlar Kanunun 484 'üncü maddesi "Kefaletin sıthhati..."

\footnotetext{
${ }^{37}$ Giovanoli. Att.493, N.5.

${ }^{34}$ Oser/Schönenberger Art.483, N. 47; Rein. 31; Giovanoli, Art.493. N.13; Tuğ. 109;

Reisoğlu. 45; OR/Pestalozzi, Art.493. N.4; Grassinger, 122; Tandoğan, Geçerlilik, 39.

"Reichel. 174 vd.: Tobler, 11.47 vd.; Lerch/Tuason, 36-37; Becher, Att.493. N.8; Giovattoli. Art.493, N.3; Müllcr, 78. 79, 80; Anderegg. 12; Wacke, 17; Olgaç, 17-18, 57; Giger, 127; Grassinger, 98; BGE 42 II 149 E.3; Y IBK 12.04.1944. 14/13; Y.2I.HD E.2000/2133 K.2000/2I17 (YKD 2000. 933); Y.19.HD E.1999/1901 K.1999/2434 (YKD 1999. 1426. 1427): Y.II.HD E.2002/630 K.2002/4497 (YKD 2002. 1813); Y.19.HD E.2000/6362 K.2001/234 (Y'KD 2002.425).

(1) Tobler. 9 .

+l von Tulhr. 225; Lerch/Tuason. 15 vd., 38; Beck. Att.493. N.24 vd.: Anderegg. 9: Reisoğlu. Rücu, 473; Reisoglu. 52; Wacke, 17; Giovanoli, Art.493. N.16, 19; Olgaç. 17 vd.; Tandoğan. 553-554; Bucher, 291; Tuğ, 108; OR/Pestalozzi, Art.493. N.10; Tandoğitn. Geçerliłik, 43: Grassinger, 105; Aral, 453, 455; BGE 117 Il 490 E.3; bkz. Y.19.HD E.2000/6924 K.2000/665 (YKD 2001, 1858); BGE 100 IB 37 E.3.

42 Lerch/Tuason. 15; Anderegg. I1; Reisoğlu (Muteberlik). 384; Wacke.17; Reisoğlu, 52; Yavuz 765: Elçşirel bakış için băz. Hatemi/Serozán/Arpacı, 525.

${ }^{43}$ Beck. Ar.493. N.26; Anderegg. 11; Wacke.17: Reisoğlu. 52
} 
diyerek şekil şartınm geçerlilik şartı olduğunu hükme bağlamıştır. Kanunun bu hükmü olmasa da BK 11/IY'nci maddesine göre şekle aykırılık sözleşmenin geçersizliği sonucunu doğururdu.

Geçersizliğin türünün mutlak butlan ${ }^{45}$ olduğu görüşü dışında kendine özgü geçersizlik ${ }^{4 !}$ olduğu gibi görüşler de ileri sürülmüşşür..

Mutlak butlan görüşij kabul edildiğginde, hakim, kendiliğinden kanunen emredilmiş şekil şartına uyulup uyulmadığını inceler ${ }^{47}$. Taraflardan birinin şekle aykırılığı ileri sürmesi zorunlu değildir.

Geçerlilik şekline aykııllık kefaletin yazılı şekilde yapılmaması örneğin sözlïi yapılmasında söz konusu olabileceği gibi kefilin sorumlu olduğu miktarın kefalet senedinde belirtilmemesi halinde de söz konusu olur.

Gerekli şekil şartı yerine getirilmemişse veya esaslı bir unsur bu şekil içinde yer almamışsa sözleşme tamamen geçersizdir. Ancak sorumluluk miktarmın bir kısnı gibi işlemin bir bölümünün şekil içinde yer almaması halinde ilgili kısım veya şart batıl olur ${ }^{48}$. Kefalet sözleşmesinde çeşitli hükümler bulunuyor ve bu hükümlerin bazıları şekil kuralına aykırı olarak sözleşmeye yazılmamışsa, diğer bir ifade ile şekil sözleşmenin tamamını kapsamiyorsa bu durumda BK 20/II ye göre kısmi butlandan söz edilebilir ${ }^{49}$. Kefalet sözleşmesine konu olan meblağın bir kısmı yazılı şekil şartına uygun olarak belirtilmişse veya müteselsil kefalet şartedilmek istenitken bu husus şekle aykırı olarak yazılmamışsa kısmi butlandan söz edilebilir ${ }^{50}$. Buna karşılık kefïlin imzasının bulunmaması veya yazılı metinde anlaşmanm

\footnotetext{
${ }^{4}$ bkz.s.3 dn. 18 .

${ }^{45}$ Oser, 860; Reichel, 178; von Tuhr, 225; Tobler. 9; Lerch/Tuason, 37; Becker. Art.493, N.7; Rein, 41; Frey, 45. 46; Beck, Art.493, Nr.15. 16; Anderegg, 57; Reisoğlu, Muteberlik, 390; Oğuzman, 249; Giovanoli, Art.493. N.3. 11; Giger, 127; Wacke. 17. 19; Anderegg. 57; Aral. 445; Reisoğlu. 44; Bucher. 292: Tandoğan, 540; Hatemi/Serozan/Arpacı. 524; OR/Pestalozzi, Art.493, N.3; Grassinger, 99; BGE 42 I[ 149 E.3: BGE 1 l] II 28 ] E.d; Y I3 HD 26.l.1989-5996/333 (Nazif, Kaçak. Yargıtay İçtihatları Külliyatı ll.Cilt. Ankara 1999). Y IBK $30.09 .19982 / 2$.

th Ayruntılı tartışmalar ve önerilen diğer yollar için bkz. Müller, 22 vd.; Eren. C.1, 267 vod.; Tuğs. 130 vd.: Koller. 100 vd.: Kocayusfpaşaoğlu. 246-247; Altaş. 89 vd.

${ }^{47}$ Furrer, 52; Beck. Art.493, Nr.15; Tăndoğan, 540; Tandoğan. Geçerlilik, 37: Tuğ. 109; Bilge. 373; Wacke, 18; Reisoğlu, 44; Y IBK 12.04.1944. 14/13; Y IBK 30.09.1988 2/2; Y.19.HD E.1999/190I K.1999/2434 (YKD 1999, 1427); Y.21.HD E.2000/2133 K.2000/2117 (YKD 2000, 933).

${ }^{4 x}$ Reichel, 179; Becker. Art 493. N.14; Beck. Art.493. Nr.16; Grassinger, 11 1 -112; Reisoğlu. Muteberlik. 374-375; Oser/Schönenberger. Art 493, N.46; BGE 60 II 98.

${ }^{19}$ Tobler, 47: Beck, Art.493, N.16: Giovanoli. Art.493. N.I1: Tandoğan, 541; Başpınar. 108; OR/Pestalozzi. Art.493. N.3; BGE 60 [I 98, BGE 43 II 5I5; Koller, 137. Yazar kusmi butlan bükmünün şekil şartına bağlı sözleşmelerde kıyasen uygulanabileceğini belirtmektedir.

\$1 Beck, Art.493, N.20; Oser/Schönenberger, Art.493. N.46: Giovanoli, Art.493. N.11; Grassinger, 111; Reisoğlu. 45: Reisoğ
} 
kefalet sözleşmesi olduğunun anlaşılmaması hallerinde sözleşmenin tam olarak geçersiz olduğunu söyleyebiliriz"

Kefil, kefalet sözleşmesi şekle aykırılık nedeniyle geçersiz olması halinde alacaklının kendisine başvurması halinde bu geçersizliği bir itiraz olarak ileri sürecektir ${ }^{52}$. Bu durumda alacaklı şekle uygun bir kefalet sözleşnesi yapımasını talep edemeyeceği gibi tazminat talebinde de bulunamaz. Şekle aykırı sözleşmenin ifası talep edilemez. Şeklin yerine getirilmesine ilişkin bir dava da açılamaz. Zira dava edilebilir bir alacak hiç doğmamıstır. Bunun dışında şeklin tamamlanması veya yenilenmesi talep edilemez ${ }^{53}$. Ortada eksik bir borç bile yoktur ${ }^{54}$. Şekle aykırı sözleşme şekilkurallarına uyan başka bir sözleşme kurma yükümlülüğỉ doğurmaz. Kefilin icazeti geçerlilik sağlamaz.

Kefilin şekle aykırı surette yapılan kefalet sözleşmesine sonradan icazet vermesiyle sözleşme geçerlilik kazanmaz ${ }^{5.5}$.

Ifanın talep edilmesi halinde kefilin şekil şartına aykırılık veya eksiklik nedeniyle sözleşmenin geçersiz oldugunu ileri sürmesi ilke olarak hakkın kötüye kullanılması olarak değerlendirilmez ${ }^{56}$. Kefilin kefalet sözleşmesinden kaynaklanan yükümlüliłğ̈ünün ağırlığını ve kapsamını tam anlamiyla bilmesi bu durumu değiştirmez ${ }^{57}$. Ancak kefil bu tür bir geçersizlik nedeniyle diğer şartlarının bulunması halinde BK md.41/II'ye göre ahlaka aykırı şekilde başkasına zarar vermekten sorumlu olabilir ${ }^{\text {s\& }}$. Taraflar arasında kurulan sözleşmenin şekil kurallarına aykırılık nedeniyle geçersiz olması ve bu nedenle ifa edilmemesi, tek başına ahlaka aykırı surette başkasına zarar verme durumu oluşturmaz. Kefil alacaklıya bir zarar vermek amacıyla daha sonra ileri sürmek için şekle aykırı bir sözleşmeyi

st bkz.Başpınar, 109.

52 Grassinger, 98, 123 vd.; Y.IBK 12.04.1994 14/13.

${ }^{53}$ Reichel. 178; Oser/Schönenberger. Art.11, N.30; Beck. Art.493, N.17. 19; Anderegg. 59; Reisoğlu, 44; Giger. 63; Tandoğan, Geçerlilik, 37; Tŭ, 109; BGE 50 ll 253; BGE 49 Il 63 ff.; Y IBK 30.09.1998 2/2.

54 Oser/Schönenberger. Art.11 N.30; Beck, Art.493, N.17; Anderegg, 60; Wacke, 20.

${ }^{55}$ Reisoğlu, 44; Beck. Art.483 N.20; Reisoğlu, Muteberlik. 375; Grassinger. 99; Zımni olarak kefaletin kabulü için bkz. BGE 40 Il 61 I , BGE 50 II 292.

St Reichel. 178; Becker. Art.493, N.7; Beck, Art.493. Nr.18; Oguuzman, Suistimal, 249; Reisoğlu. Muteberlik, 390; Reisoğłu. 45. 58; Giovanoli, Art.493, N.12; Tandoğan, 54I; Tandoğan, Geçeriilik, 38; OR/Pestalozzi. Art.493, N.3; Grassinger, 121; Y IBK 31 .09.1988 2/2; BGE 65 II 237 E.2; BGE 54 II 331; Anderegg. 59. Şekle aykırı sözleşme şekil kurallarına uyan başka bir sözleşme kurma yükümlülüğü de doğurmaz: Wacke, 18. Zira şekil hükmü kefili korumak için öngörülmüştür.: Taşınmaz satımt için bkz. Koller, 125 vd.; Kefalet sözleşmelerinde dürüstlük kuralına uygun davranma zorunlujư̆ts en üst seviyededir (Becker, Art.492. N.6; OR/Pestalozzi, Art.492. N.3).

${ }^{57}$ Giovanoli. Art.493, N. 12; Beck, Art.493, Nr.18. Alacaklının kefaletin geçerli olacağına ilişkin iyiniyeti dururnu değiştimez (aynı yer).

${ }^{54}$ Giovanoli, Art .493, N.12; Reisoğlu, 59. 
kasten yapmış ise hakkın kötiiye kullanılmasından söz edilebilir" ${ }^{59}$. Bu durumda culpa in contrahendo dan kaynaklanan bir haksız fiil ortaya çıkar ${ }^{(\alpha)}$.

Kefilin sonradan ileri sürmeyi düşündüğü şekil eksikliğini alacaklıya kasten yaptırması halinde şekil eksikliģine dayanması hakkın kötüye kullanilması olur ${ }^{61}$.

Kefil, kasten şekil şartına uyulmadığı halde karşı tarafa ifada bulunur, bu yolla alacaklının asıl borçluya kredi açmasını sağlarsa BK 4I/II anlamında bir zarardan ve tazminattan söz edilebilir ${ }^{62}$.

\section{III. ŞEKİL SARTINA UYULMADAN YAPILAN KEFALET SÖZLEŞMESİNDE KEFILIN BORCU IFA ETMESININ SONUÇLARI}

\section{A. Genel Olarak}

Şekil şartına uyulmadan yapılan kefalet sözleşmesinde kefil ifadan önce her zaman şekle aykırılığı ileri sürebilir. Bu durum şeklin koruma amacından dolayı hakkın kötüye kullanılması olarak değerlendirilemez ${ }^{63}$.

Bir borca kefil olan kişi, kefalet sözleşmesi şekle aykırılık nedeniyle geçersiz olduğu halde bu durumu bilmeden borcunu ifa edebilir. Kefalet borcunun ödenmesine ilişkin bir ihtara veya icra dairelerince gönderilen ödeme emrine muhatap olan kişi imzaladığı kefalet sözleşmesinin geçerli olduğunu düşünerek ödeme yapabilir. Bu kişi böyle bir ihtar veya ödeme emri almaksızın sadece borcun yerine getirilmedigini ögrenerek herhangi bir hukuki takibata maruz kalmamak amaciyla alacaklıya ödeme yapabilir. Kefalet borcunun ödenmesi halinde alacaklı, ödemeye karşı bir itirazda bulunmaz. Kefalet sözleşmesinin gerekli şekil şartlarını taşımaması ile de ilgilenme yükümlülüğü bulunmayan alacaklı ödemeyi kabul eder.

Kefalet borcunu yerine getirdiğini düşünen kefilin yapacă̆ı en normal davranış borçluya rucu etmek olacaktır. Kendisine rucu edilen borçlunun

\footnotetext{
9y Wacke, 19; Beck, Art.493, N.18; Oser/Schönenberger, Art.11, N.30; Giovanoli, Art.493, N.12; BGE 65 II 237, 57 II 154; BGE 54 ll 332; Böyle bir durum kefilin kasten ve geçersiz olduğunu bildiği halde sözleşmeye borçlunun tüm borçlarına kefil olduğunu yazması şeklinde ortaya çıkabilir; Özellikle alacaklt aldatılarak veya sırf daha sonsa şeki] eksikliğinden kaynaklanan geçersizłiğe dayanmak için şekle aykırı kefalet sŏzleşmesi kurulmuşsa bu durum hakkın kötüye kullanılması oluşturaçă̆ı gibi alacakltya kefile karşı müspet zararının tazmini isteme hakkı yantnda BK 4l/II ye göre tazminat talep etme hakkı verir (bkz. Aral, 452).

${ }^{*}$ Beck, Art.493, N.18; Oser/Schönenberger, Art.1 I, N.32.

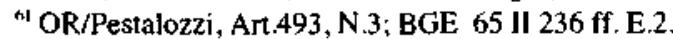

Anderegg. 60: Reisoğlu, 58-59; Rejoğglu, Muteberli, 390; Tandoğan, 541; BGE 50 Il 292.

${ }^{\text {a3 }}$ Reichel, 178; Anderegg, 59; Reisoğlu, 58; BGE 42 II 154; Merz, N.472. Ancak bu tŭr durumlarda hile söz konusu olursa tazminat yỉkümlüłügü söz konusu olur.
} 
kefili tatmin etmesi durumunda bir sorun çıkmayacaktır. Ancak borçlunun kefili tatmin etmemesi diğer bir ifade ile borcunu ödememesi halinde kefalet borcunu yerine getiren kefil zor duruma düşecektir. Bu durumda kefilin borçlu rarafindan ileri sîrülen geçersiz bir sözleşmeyi yerine getirdiği, bu nedenle de kendisine rucu imkanı bulunmadığı itirazı ile karşılaşması mümkündiür. Kefil böyle bir itiraz dışında rucu imkanmı kultanırken veya ifadan sonraki bir zaman diliminde kendiliğinden kefalet sözleşmesinin şekle aykurılık nedeniyle geçersiz oldı̆̆unu ögrenebilir. Kefilin bu durumunu sözleşmenin geçersiz olduğunu bilerek veya bilmeyerek odeme ihtimallerinde ayrı ayrı değerlendirmek gerekmektedir.

\section{B. Alman Hukukında Bulunan Özel Durum}

Alman Hukukunda şekle aykırı yapılan kefalet sözleşmeșinin ifası BGB \$ 766'da dïzenlenmiştir. Bu dïzenlemeye göre geçerlilik şekli olan yazılı şekil şartı yerine getirilmediği halde kefil sözleşmeden kaynaklanan asıl edimini yerine getirirse geçersiz kefalet sözleşmesi sağlık kazanır. Bu durumda kefil sadece asıl borçluya rucu imkanına sahip olur. Kefil yaptığı ödemeyi borcun varlığ konusunda yanılmış olsa bile alacaklıdan geri talep edemez $z^{\text {tit }}$.

BGB § 766 düzenlemesi değerlendirilirken şekle aykırı kefalet sözleşmesinin yerine getirilmesi halinde sebepsiz zenginleşme talebinde bulunamama hükmünün izahı, şekil eksikliğine bağlanan geçersizliĝ̣n türünỉn bir eksik borç ilişkisi yaratmış olmasma dayandırılmıştır.

Alman Hukukunda bulunan ve condicti in debiti kurumusu düzenleyen (BGB \$ 814). Türk/Ísviçre Hukukunda yer alan düzenlemeye gơre (BK .62) kefili daha çok korumaktadır ${ }^{60}$. Zira BGB de ödeyenin edimi yerine getirmeye yükümlü olmadı̆̆ını bilmemesi şartı aranırken. Türk/İsviçre Hukukunda ödeyenin borçlu olduğuna dair hataya düştüğünü ispat edebilmesi şartı aranmaktadır. Edimi yerine getirmekle yükümlü olmadıł̆ıı bilmemek, konumuz bakınından şekle aykırı bir kefalet sözleşmesi olduğunu ve bunun geçersiz olup bir borç doğurmayacağını kişinin bilmemesini ifade eder. Kişi bu durumu bilmiyorsa, Alman Hukukunda ödediğin geri talep edebilir. Buna karşlık Türk/Isviçre Hukukunda, kefilin sözleşmenin şekle aykırı olduğunu veya şekle aykı̆ı sözleşmenin geçersiz olduğunu dolayısıyla bundan kendisi aleyhine bir borç doğmayacağını bilmediğini ve bu konuda hataya düştügünì ispatlaması gerekmektedir. Diğer bir ifade ile Alman Hukukunda kefil kendini borçlu sanıyorsa verdiğinin iadesini talep edebilir. Türk/1sviçre Hukukunda kendini borçlu

\footnotetext{
(H) Wacke. 20: Yapilat odemenin ifa olarak kabul edilmesi yeterlidir (Miiller. 81)

"Wacke. 20.

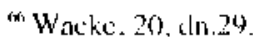


sanmaya hata ile düşmüşse yani kefaletin geçerliliği konusunda, hataya duişmiussse verdiğini geri talep edebilir.

\section{Sözleşmenin Geçersizliğini Olduğunu Bilmeyen Kefilin İfada Bulunnatası}

\section{Sebepsiz Zenginleşme Talebi (BK m.62)}

\section{a. Genel Olarak}

Asıl borçluya rucu imkanını kullanamayan ve geçersiz kefalet sözleşmesinden dolayı borçlu olduğu inancında olan kefil, yaptığı ödemeyi alacaklıdan talep edebilir. Sözleşmenin geçersiz olduğunu bilmeyen kefil talebini ilke olarak sebepsiz zenginleşmeye dayandırmalıdır". Ancak bu talep için gerekli şartların da somut olayda bulunması gerekmektedir.

Sözleşmenin geçersizliğini bilmeyen kefilin alacaklıya ödemede bulunması kefalet sözleşmesini geçerli hale getirmez. Bu sonucun elde edilmesi için bazı şartların bulunması gereklidir ${ }^{68}$.

${ }^{67}$ von Tuhr, 225; Tobler, 10: Lerch/Tuason, 38; Rein. 41; Frey, 45; Beck, Art.493, N.21; Anderegg, 62; von Tuhr/Peter, 478 vd.; Furrer, 61: Müller. 452; Reisoğlu, Muteberlik, 391 ; Wacke, 20; Reisoğlu, 45, 59: Frey. 46; Rcin, 61; Tandoğan, 540-54I; Tandoğan, Geçerlilik, 37; Bucher, 293; OR/Pestalozzi. Art.493. N.4; Grassinger. 99; Aral, 445. BGE 64 II 12 l E.4; 70 II 271 ff. E.4; Giovanoli. Art.493. N.12; Isviçre Borçlar Kanunu 20 Aralı 1939 tarihli kefalet hukuku revizyonu için hazıtlanan tasarımın Art 494 Abs 4 geçersiz bir kefalet sözleşmesi nedeniyle yapılan ödemenin sebepsiz zenginleşme hükümlerine göre geri alınabileceği açıkça öngörülmüştü. Ancak bu hüküm genel olarak geçcrli bir ilkenin tekraranıdan başka bir şey ifade etmeyeceği için lüzumsuz görülmüş ve çizilmiştir Bkz.. Protokoll I der nationalrätlichen Kommission S.27; Protokolt l der ständerätlichen Kommission S.27; StenBull NR 1940 S.75.78; StenBull StR 194 S..406 (BGE 70 II 272 E.4'ten nakien): Reichel'e göre (178-179) kefilin geçersizliği bilmesinin mümkün olmadığı hallerde kefil korunmaz. Çünkü şekil hükümleri kefili sadece yükümlülük altına girmeye karşı korur yoksă ifaya karşı değil. Bu durumda Reichel'in şekle aykırıltğı bilecek durlında olmayan kefilin sebcpsiz zenginleşme talebinde bulunamayacağını iddia ettiğini anliyoruz. $\mathrm{Bu}$ görüşe katılmıyoruz. Şekle aykırılığ bilmeyen kefilin ifadan sonra şekle aykırılığa dayanması ifadan önce bu aykırılığa dayanması gibi mümkündür (Müller, 82 ); Lerch/Tuason (38) kefalet sözleşmesinde şekil şartının kefili düşüncesizce borçlandırıcı muamele yapmaktan korumayı amaçladığını. aslında kefili ifadan korumak gibi bir amacınıı bulunmadığın, bu nedenle de şayet kefil ifada bulunmuşsa iade talebinin hakkın kötüye kullanılması olarak değerlendirmesi gerektiğini ifade etmektedir. Bu görüşe katılmıyoruz. Kefil kendini borçlu sanarak ifada bulunmantş bu nedenle BK m.62 hübmüne dayanamámış ise BK $\mathrm{m} .6 \mathrm{l}$ 'e göre de sebepsiz zenginleşme talebinde bulunamaz (Oğuzman/Öz, 239).

\& bkz.s.16-17. 


\section{b. Kefilin Sebepsiz Zenginleşme Talebinin Şartlart}

Kendisini borçlu sanarak başka birine ifada bulunan kişinin verdiğini geri talep etmesinde, sebepsiz enginleşme talebinin ileri sürülmesi için gerekli olan, gerçekleşmeyen bir sebebin varlı̆̆ şartı veya zenginleşmeye yol açan sebebin sonradan ortadan kalkması şartı aranmaz" ${ }^{\prime \prime}$.

Borçlar Kanunun 62'nci maddesine göre sebepsiz zenginleşme talebinin ileri sürülmesi için ödenmesi gereken bir borcun bulunmamas ${ }^{70}$, kefilin ödemeyi ifa amacıyla yapmış olmasi", ifanın istenerek diğer bir ifade ile kefilin serbest iradesi ile yapılmış olması ${ }^{72}$ ve kefilin borcun varlığı hakkında yanılmış olması gerekir.

Kefil hileye düşürülerek, tehditle veya muzayaka halinde iken ya da icra takibi sonucunda ödemede bulunmuşsa bu şart gerçekleşmemiş demektir ${ }^{73}$.

Kefilin sebepsiz zenginleşme talebinde bulunması sözleşmenin geçersiz olduğunu bilmeden kendisini borçlu sanmasına bağlıdır ${ }^{74}$. Konumuz bakımından hata ile kendini borçlu sanma ya da borcun varlığı hakkında yanılgı şekle aykırı sözleşmenin geçerli olduguna ilişkin inançtır.

Kefilin ifa esnasında borçlu olduğuna jlişkin yanlış tasavvuru hata olarak değerlendirilir ${ }^{75}$. Borçlu olup olmadığı konusunda şüphe varsa hatadan söz edilemez. Bu tür durumlarda ifa esnasında hak saklı tutulmamış ihtirazı kayıt konmamıssa iadenin talep edilmesi münkün değildir. Hataya düşülerek borcun ifa edildiğine ilişkin ispat yükü ödeyen taraf olan kefile düşmektedir ${ }^{76}$.

${ }^{\theta}$ Gauch/Schuep/Jäggi. N.1531.

${ }^{70}$ Eren, 871; Oğuzman/Öz. 240: Gauch/Schuep/Jäggi, N.1530. Bu borç ya hiç doğmamıştır ya da ifa edilmeden önce sona ermiştir.

"von Tuhr/Pcter, 478; Eren, 872; Oğuzman/Öz, 239-240.

${ }^{72}$ Tobler. 10; Beck, Art.493, N.21; von Tuhr/Peter, 485, 486; Schwenzer, 327: Eren, 872.

${ }^{73}$ Tobler. 10; Beck, Art.493. N. 21; Oser/Schönenberger, Art.63, N.8; BGE 63 II 169 E.2; Tandoğan, 541; Tandoğan, Geçerlilik, 37; Gauch/Schuep/Jäggi, N.1537, 1539; von Tuhr/Peter, 485; Schwenzer, 327; Eren, Il, 872; BGE 64 Il 127; İcra Hukuku kuralları nedeniyle ödeme zorunda kalan kefil İlK m.72/VII ve VIIl'e göre iade davası açmalıdır (Grassinger. 99; Beck. Art.493, N.21).

${ }^{74}$ von Tubr. 225; Lerch/Tuason, 38; Oser/Schönenberger. Art.63, N.8, Art.494, N.44; Rein. 41; Frey, 45; Beck. Art.493, Nr.21 ; Merz, N.475; Furrer, 60; von Tuhr/Peter, 483; Anderegg, 62; Wacke, 20; Giovanoli. Art.493, N.12; Giger. 127-128; Reisoğlu. 59; Tandoğan, 540; Tandoğan, Geçerlilik, 37; Oğuzman/Öz, 242-243: Gauch/Schluep/Jäggi, N.1529; Schwenzer, 327; Eren, 872; Grassinger, 99; Koller, 122-123; Aral, 445, 452; Reisoğlu, 59; BGE 64 II 127 E.5 a; BGE 41 II 485; BGE 40 II 253; BGE I15 If 28 E.1: Reichel (178), kefil sözleşmenin geçersiz olduğunu bilse dahi sebepsiz zenginleşme tałebinde bulunutabileceğini ileri sürmektedir. Bu görüşe katılmıyoruz.

${ }^{75}$ Gauch/Schluep/Jäggi, N.1533; Eren, 872.

Th von Tuhr/Peter, 484, 486: Gauch/Schluep/Jäggi, N.1533-1535; von Büren, 299-300; Schwenzer, 327: Eren, 872. 
Kefil hukuki hataya dişse bile sebepsiz zenginleşme talebinde bulunabilir $^{77}$. Hukuki hata kefalet sözleşmesinin şekil kuralına aykırı yapıldığını bilmemek diğer bir ifade ile kefaletin bir şekil şartına tabi olduğunu bilmemek veya bu şekle uyulmasa dahi sözleşmenin geçerli olduğuna inanmak şeklinde ortaya çıkar.

Borçlar Kanunun 23 ve devamındaki maddelerde düzenlenmiş bulunan esaslı hata ve esaslı olmayan hata ayırımı BK m.62 bakımından deger taşımaz. Zira doğmamış bir borcun ödenmesinde kefilin davranışının esaslı olmayan hata kapsamında değerlendirilmesi doğru degildir. Sebepsiz zenginleşme talebinin ileri sürülebilmesi için $\mathrm{BK} \mathrm{m} .62$ anlamında bir hatanın bulunması yeterlidir.

Kefilin düsstüğư hatanın mazur görülecek bir hata olması şartı aranmamaktadır $^{78}$. Sebepsiz zenginleşme kurumunun yapısı bu çözümü destekler niteliktedir. Sebepsiz zenginleşme talebi ile bir sebep bulunmadan başka bir kişinin malvarlığında artış olması halinde bozulan denge sağlanmak istenmektedir. Bu amaca ulaşmak için dayanılan asıl kavram ise hata değil sebepsiz zenginleşmedir ${ }^{79}$.

Kefilin sebepsiz zenginleşme talebinin hakkın kötüye kullanılması oluş̧urduğu ilke olarak ileri sürülemez. Zira kefalette şeklin amacı kefili korumaktır ${ }^{80}$.

\section{Sebepsiz Zenginleşme Talebinin Muhatabı}

Bir görüşe ${ }^{81}$ göre sebepsiz zenginleşme talebi alacaklıdan başka bir kişiye (asıl borçluya) yöneltilemez. Zira kefil, asıl borçlunun borcunu deģil

\footnotetext{
${ }^{\pi}$ Tobler, 10; ; Oser/Schönenberger, Art.63, N.8; Rein, 41; Beck, Art.493, N. 21; von Büren, 299; Wacke, 20; von Tuhr/Peter, 483; Reisołlel, 59; Gauch/Schluep/Jaggi, N.1534; Eren, 872; BGE 70 II 271; BGE 64 II 127; BGE 41 II 485; 40 II 253; BGE 107 II 258; Anderegg. 62-63. Yazara göre hukuki hatanın dikkate alınmaması ve sebepsiz zenginleşme sartı oluşturmaması ne Borçlar Kanunundaki düzenlemeden ne de eski İsviçre Borçlar Kanunu (aOR) Art.72'den çıkartılabilir.

${ }^{7 *}$ Tobler, 10; Beck. Art 493, N.21; Reisoł̆lu, Muteberlik, 391; von Büren. 299; Reisoğlu, 59; von Tuhr/Peter, 483-484; Tandoğan, 541; Tandoğan, Geçerlilik, 37; Oǧuzman/Öz, 245; Gauch/Schluep/Jäggi. N.1534; BGE 64 II 127 E.5e; Eren, 872. Yazar mazus görülmesi mümkün olmayan kusura dayanan batanın dahi yeterli olacağını, ancak bu durumda BK m.26'nın tazminata hükmedilme açısından kıyasen uygulanması gerektiğini ifade etmektedir. Aynı şekilde bkz. Oğuzman/Öz, 244; von Tuhr (225) hatanın mazur görülmesi şartı aransa dahi hukuki hatantn mazur görülebileceğini, asłında bu tür olaylarda kefilin yanhı̧lıkta ifasının çok sık görüldügưnüi belirtmektedir. Ona göre bilgisiz veya tecrübesiz bir kişiye kusur izafe edilememelidir.

${ }^{79}$ BGE $6411121 \mathrm{ff}$.

${ }^{32}$ Rein, 41.

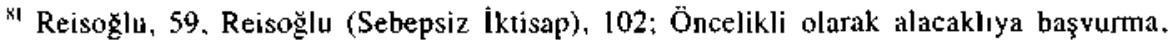
̧̧artları varsa asıt borçluya başvurma görüşui için bkz. Grassinger, 100; BGE 70 II 271 E.4.
} 
kendi borcunu ödemektedir. Ifa ile kefilin alacaklıya karşı olan borcu sona ermektedir.

Şekle aykırı olarak yapılan kefalet sözleşmesinin geçersiz olduğunu bilmeden ödemede bulunan kefil sebepsiz zenginleşme talebini alacaklıya yöneltmelidir. Bu ödeme kefalet borcunun ifası niteliğinde değildir. Kefilin ifasına rağmen alacaklı ile asıl borçlu arasında bulunan borç ilişkisinden kaynaklanan alacak devam etmektedir. Ifa sonucunda alacaklmm malvarhığınn aktif kısmı hem kefil tarafından yapılan ödeme ile artacak hem de asıl borçluya karşı var olan alacak hakkı varlığını devam ettirdiğinden artacakur. O halde sebepsiz zenginleşen kşi alacaklıdır.

Dị̆er bir görüşe göre ${ }^{82}$ bazı durumlarda kefỉl asıl borçluya karşı sebepsiz zenginlȩ̧me talebinde bulunabilir. Bu görüşe göre, alacaklının iflas etmesi veya başka bir surette kendisinden alacağm tahsil edilemediğ durumlarla hatamın ispatının yapılamadığı durumlarda kefile asıl borçluya karşı sebepsiz zenginleşme talebi ileri sürme hakkı tanınmalıdır.

Kefilin asil borçluya sebepsiz zenginleşme talebi ileri sürebilmesi için, ilk olaratk, alacakltya karşı kullanabileceği sebepsiz zenginleşme talebinden feragat etmesi veya bu alacağın zamanaşımına ugraması gerekmektedir. İkinci olarak ise asıl borçlunun. kefil tarafından ödemenin yapılmış olması nedeniyle. herbangi bir şekilde alacaklının talebiyle karşılaşmayacağı dưumưa bulunması gerekmektedir ${ }^{x^{3}}$. Zira bu durumda borçlu sebepsiz zenginleşmiş olacaktır. Kefilin alacaklıya karşı ileri sürebileceği sebepsiz zenginleşme talebinin zamanaşımına uğraması veya alacaklının iktisabının geri dönülemez şekilde kesinleşmesi halinde de asıl borçluya karşı sebepsiz zenginleşme iddiası ileri sürülebilir. Ancak bu nedenle assıl borçlunun hukuki durumu mevcut halinden daha kötü hale getirileme $z^{34}$.

Yarğtay ${ }^{x:}$ da sebepsiz zenginleşme talebinin borçluya yöneltilmesi gerektiŏini ileri sürmektedir. Yargıtay kefilin alacaklıya ödeme yapması ile alacaklı ile assl borçlu arasında bulunan borcun sona erip ermeyeceği belirlemesini katarına esas almıştır. Ödeme ile alacaklı ile asıl borçlu arasında bulunan alacak sona eriyorsa alacaklı alacağını almış buna karşılık borçlu borcundan kurtulmuş olacaktır. Bu durum borçlunun malvarlığından sebepsiz bir artışa yol açacak ve sebepsiz zenginleşme talebine muhatap olacaktır. Yargıtay'ın görüşünün ayrıntılı olarak değerlendirilmesi gerekmektedir. Yüksek Mahkeme "...ödeme sonucu alacak sonat ermişse..." ifadesini kullanmaktadır. Gerçekten kefilin öłlemesi ile alacaklının asıl borçluya karşı sahip olduğu alacak sona eriyorsa assl borçlunun da kefil aleyhine sebepsiz zenginleşmiş olması mümkündür. Ancak, bu konuda ilk

\footnotetext{
* OR/Pestalo\%i. Ant 493. N.4; BGE 70 11274 f. E.5; 3.HD 06.04.1989 94.31/3528 (Reisoğlu. $6(0$, dn.253 ten natilen).

${ }^{4.3}$ BGE 7011274 f. E. 5 .

${ }^{* 4}$ OR/Pestalozzı. Art 493. N.4; BGE 70 Hl 274 I. E.5.

${ }^{* 4} Y$ 3.HD (06.04. $19899431 / 3528$ (Reisoğlu. 60. dn 253 'ten naklen).
} 
olarak belirtilmesi gereken husus kefilin kendi borcunu ödeme amacıyla hareket etmiş oldığudur. Kefil kendi borcunu ödeme amacıyla hareket ediyorsa alacaklımın asıl borçluya karşı sahip olduğu alacağı sona ermez. Bunun dışında kefilin alacaklıya yaptığı ödemeyi başkasının borcunu onun muvafakati veya talimatı olmadan ifa etme olarak değerlendirmek mümkün değildir. Zira kefil asıl borçlunun borcunu ifa etmek amacıyla ödeme yapmamıştır. Bu nedenle BK m.109'a göre kefil asıl borçluya halef olamaz. Benzer şekilde kefil asıl borçluya bağışta bulunmak amaciyla da ödeme yapmamıştır. Bu nedenlerle kefilin asıl borçluya sebepsiz zenginleşme talebinde bulunması mümkün değildir.

Biz Federal Mahkeme ve Yargıtay tarafından savunulan görüşe katılmiyoruz. Zira, alacaklınm sebepsiz zenginleşmesini alamayan kefil asıl borçluya rucu etmelidir. Asıl borçlu kefalet sözleşmesinin geçersizliğini ileri sürecek olursa, kefilin şekil şartının koruma amacını gerçekleştirdiği ve hakkın kötüye kullanıldığı savunması yapmalıdır ${ }^{86}$. Sebepsiz zenginleşme kurumunun zorlanarak kefile asıl borçluya karşı sebepsiz zenginleşme talebini ileri sürme hakkının tanınmasım isabetli bulmuyoruz.

\section{Kefili Koruyan Başka Bir Yol var mıdır?}

\section{Genel Olarak}

Şekle aykırı kefalet sözleşmesini kendini borçlu sanarak ifa eden kefilin BK md.62'ye dayalı sebepsiz zenginleşme talebinden başka başvurabileceği bir yol bulunup bulunmadığının, kefilin alacaklıya yapuğı ödeme geçerli bir ifa sayılarak asıl borçluya rucu imkânı sağlayacak bir yol olarak sözleşme geçerli olarak değerlendirilip değerlendirilemeyeceğinin ${ }^{87}$ son olarak da şekle aykırılığ bilerek ifada bulunan kefilin asıl borçluya karşı bir talep hakkına sahip olup olmadığınn incelenmesi gerekmektedir.

\section{Durumu}

\section{Sözleşmenin Geçersiz Olduğunu Bilmeden İfada Bulunan Kefilin}

Alacaklının iflas etmesi veya başka bir surette kendisinden alacağın tahsil edilemediği durumlarla hatanın ispatının yapılamadığ kefilin geçerli bir ifada bulunduğunu kabul ederek asıl borçluya rucu etme imkanını sağlamak alacaklıya büyük yarar sağllayacaktır.

Butlan görüşünü savunanlara göre kefil sadece BK $m .62$ hükmünden yararlanabilir. Bunun dışında sözleşmenin geçerli sayılması ${ }^{88}$ ve borçluya rucu mümkün değildir.

\footnotetext{
wh bkz. S.16-17

${ }^{87}$ Wacke, 21.

"skz.s. $7 \mathrm{dn} .45$
} 
Şekle aykırı kefalet sözleşmesi nedeniyle ödemede bulunan kefili mutlaka alacaklıya karşı sebepsiz zenginleşme talebi yöneltmek zorunda brrakan ve kefili bu haliyle korumayan bu görüşï doğru bulmuyoruz.

Şeklin koruma amacı fiilen gerçekleşmediği halde görünüşte şekil şartları yerine getirildił̧i için şekle tabi sözleşmenin geçerliliği kabul edilmektedir. Şeklin koruma amacı gerçekleşmişse aynı kuralın şekil ફ̧artlarının görünüşte yerine getirilmediği durumlarda da uygulanması gerekir. Kaldı ki şeklin koruma amacının gerçekleştiği ve ifanın yapıldığı durumlarda $\mathrm{BK}$ m.62 dışındaki bir talebin ileri sürülmesi halinde şekle aykırılık nedeniyle geçersizlik iddiasının kabulï istenmeyen sonuçlara yol açabilir $^{89}$. Alacaklı iflas etmişse ve asıl borçluya rucu imkanı tanımmazsa kefil sadece borcunu ödemekle kalabilir. Böyle bir durumda şekil şartı sadece abartılı olarak uygulanmış olmaz ${ }^{\$ 0}$ aynı zamanda şeklin amacından da uzaklaşılmış olur. Bu tür durumlarla sınırlı kalmak üzere ve diğer şartlarının bulunması halinde geçersiz kefalet sözleşmesinin sağlık kazanacağ kabul edilebilir. Şeklin amacı geçekleşmemişse sağlık kazanmadan söz edilemez ${ }^{91}$.

Böyle bir çözüm yolu hem kefil hem de alacaklı yararına olacaktır. Asıl borçlu durumunda bulunan kişi ise sebepsiz meydana gelen malvarlığı artışını kefile rucu yoluyla vermek zorunda kalacaktır. Kefil yararına olacaktır; çünküi bu çözümün kabul edilmemesi ihtimalinde kefil zorunlu olarak alacaklıya başvuracaktır. Burada Bk md.62 hükümlerinin şartlarmm doğup doğmadığına bakılacak, muhtemelen bazı ispat güçlükleri ile karşılaşılacaktır. Özellikle kefil iflas etmiş, malvarlığını tasfiye ederek yurtdışına yerleşmiş olduğundan veya borç ödemeden aciz halinde bulundugu için alacaklıdan hiç bir şey alamayacak ve kendi zararına katlanacaktır. Kefalet sözleşmesinden ilke olarak hiçbir yararı bulunmayan kefilin bu durumda bulunması doğru değildir. Alacaklı yararına olacaktır; çünkü alacaklı alacağını kefilden almıştır ancak hali hazır bir sebepsiz zenginleşme talebi ile karşı karşıyadır. Alacaklı bu talebin mahkemece hükme bağlanması halinde aldıklarını sebepsiz zenginleşenin iadesi kapsaminda kefile verecek ve asıl borçluya yönelecektir. Alacaklınm kefilin ifasının geçerli olup olmadığı derhal bilmeye hakkı vardır. Zira uzun bir zamandan sonra bu durumu ögrenmesi, aldıklarını iade etmesi ve borçluya yönelmesi büyük menfaat kayıplarına yol açacaktır. Bunun dışında kefill bir

\footnotetext{
Müller, 82.

von Tuhr, 225.

${ }^{91}$ Müller. 82. Alman Hukukunda şeklin koruma amacının gerçekleşmiş olmasının önemi yoktur. İfanın yapıłmı olması yeterlidir (BGB \$ 766). Reichel (178-179) ișe, şekil kuralının kefiti sadece taahhüt altına girmekten koruma amacınıs taşıdığı ifadan korumak gibi bir amaç taşımadığını ileri sürmekte ve ifa gerçekieşmiş ise geçersiz sözleşmenin sağlık kazanacú̆ını iddia etmektedir. Bu görüsşe katılmıyoruz (bkz. Müller, 82). Geçersiz sözleşmenin ifadan sonra sağıłk kazanması kefilin lehine olabilir. Ancak kefilin bu durumu başkn maksatlarla hareket etmesine izin vermez.
} 
ödemede bulunmak isterse alacakh bu ödemeyi kabul etme yetkisi bulunup bulunmadığını bilmek zorundadır. Bu nedenle alacaklı, kefile başvurarak uygun bir süre içinde nasıl davranacağının kendisine bildirilmesi talep edebilir. Kaldı ki kefil, kendisini koruyan şekil hükümlerinin bu korumasından da başlangıçta olmasa bile ilişki doğduktan sonra feragat edebilir. Bu meyanda BK m.62'de yer alan alacaklıya karşı ileri sürebileceği sebepsiz zenginleşme talebinden de vazgeçebilmesi mümkündür ${ }^{92}$.

\section{Sözleşmenin Geçersiz Olduğunu Bildiği Halde Ifada Bulunan Kefilin Durumu}

Kefilin şekle aykırılığt bildiği halde alacaklıya ödemede bulunması halinde kefilin durumu hakkında iki ana görüş bulunmaktadır.

\section{a. Butlan Görüşï}

Butlan görüşüune göre ${ }^{93}$ ifa ile sözleşme geçerli hale gelmez. Bu görüş sahiplerine göre şekle aykırı kefalet sözleşmesi geçersizdir. Geçersizliğin türï ise butlandır. Böyle bir ilişki, zımni kabul veya ifa ile geçerlilik kazanmaz. Taraflar geçerli bir kefalet ilişkisi kurmak istiyorlarsa yeni ve şekle uygun bir kefalet sözleşmesi yapmak zorundadırlar ${ }^{94}$.

Kefil asıl borçlu ile arkadaşlık veya başka bir sebeple alacaklıya ödemede bulunmuşsa şekil eksikliğine dayanamaz ${ }^{95}$. Bu durumda geçersiz bir sözleşme ifa edilemeyeceğinden bir bağışlama işleminden söz etmek gerekir $^{\% 6}$. Zira, kefilin sebepsiz zenginleşme hükümlerine başvurması imkanı da bulunmamaktadır ${ }^{97}$. Kefil geçersiz sözleşmeyi bağış kastı ile ifa etmişse, alacaklının da kastının bağış olması halinde sebepsiz zenginleşme söz konusu olmaz. Kefilin bağı̧̧lama sebebi ile ifada bulunması, alacaklının ise

\footnotetext{
${ }^{92}$ Bkz.Wacke, 21.

${ }^{93} \mathrm{bkz}$. s.7. Anderegg (61), şekil kurullarına ayktrolık nedeniyle meydana gelmemiş bir kefalet sözleşmesinin konusunu oluşturan borcun kefil tarafından yerine getirilmesi geçersiz sözleşmeye esas itibariyłe sağlık kazandırmayacağını belirtmcktedir. Rein da (42) OR 63 ve ZGB 2 maddelerinin kefili yeteri kadar koruduğunu. bu nedenle de kanun koyucunun şekte aykırı sözleşmenir ifa ile sał̆lık kazanmasını hiç dủşünmediğini belirtmektedir.

${ }^{41} \mathrm{Bkz}, \mathrm{s} .7-8$

कs Müller, 81 .

* von Tuhr, 225; Anderegg, 62; Reisoğlu, Muteberlik, 392; Reisoğlu, 45: Tandoğan, 541; Tandoğan, Geçerlilik, 38; Kefilin bağışlama amacı olmaması nedeniyle biz bu görüşe katıimıyoruz. Federal Mahkeme de bu kanıdadır. Federal mahkeme kefilin hataya düşerek ifada bulunması halinde bağ borcun varlı ğ konusunda hataya düştüğü için ifada bulunduğundan bağışlama iradesi bulunmamaktadır. Bu nedenle verilenin iadesi yoluna gidilmelidir (BGE 64 II I21 ff.).

${ }^{97}$ von Tuhr. 225; Anderegg. 62.
} 
ifa sebebi ile ifayı kabul etmesi halinde sebepsiz zenginleşme söz konusu olur.

\section{b. Kendine Özgï Geçersizlik Görï̧sii}

Butlan görüşünün sert ve zaman zaman aşm sonuçlar vermesi üzerine öğretide kendine özgü geçersizlik görüşü ileri sürülmüştür. Bu görüşe göre şekle aykurılık nedeniyle geçersizliğin türünün butlan olarak kabulü halinde hakimin bunu kendiliğinden gözönüne alması gerekir. Bu butan müevyidesinin tabii bir sonucudur. Ancak böyle bir durum şekil kuralınm amacina ters düşer.

Borçlat Kanunun 20 'nci maddesinde butlan açıça zikredildiği halde BK m.ll'de "...sahih olmaz." olmaz ifadesinin kullanılmass dolayısıyla geçersizliğin tiirünün açıklanmaması kanun koyucunun kendine özgü bir geçersizlik türü istediğini destekler mahiyettedir.

Bu görüşe göre şekle aykırı bir sözleşme yapılmışsa aslında kurulduğu andan itibaren geçersiz iken taraflardan biri geçersizliği ileri sürmedikçe hüiküm ve sonıç doğurur. Taraflardan biri geçersizliği ileri sürecek olursa sözleşme baştan jtibaren geçersiz olur. Kendine özgï geçersizlik görüşünün kabul edilmesi halinde şekle aykırılığı hakim kendiliğinden gözününde tutamaz. Dava dosyasından anlaşılsa dahi hakim geçersizliğ dikkate alamaz. Zira, özel hukuk hükümleri hakim tarafından kendiliğinden uygulanamaz. Dava konusunu ise taraflar belirler. Tarafların dava ve talep etmediği bir husus hakkında hakimin kendiliğinden karar vermesi doğru değildij" ${ }^{9 \%}$.

Şekil kuralların anaçlarına göre yorumlanması gerekir. Kuralın amacı sadece tarafi korumaktır ve taraf bu korumayı görmüş ve kullanmak istememiştir. Şu halde geçersiz sözleşmeyi geçerli hale getirmek isteyen taraf iradeleri hukuk tarafindan tanınmalıdır"

b. Şekle aykırtlığın hakim tarafından kendiliğginden gözönüne alınamadığı durumlarda üçünciu kişiler de geçersizliği ileri süremez ${ }^{100}$. Zira üçüncui kişilerin hukuken korunan bir yararları bulunmamaktadır. Kaldı ki kefalet sözleşmesinde şeklin asıl borçlu ile bir bağglantısı da bulunmamaktadır. Burada ne alacaklı ne asıl borçlu korunmak istenmiştir.

Kendine özgü geçersizlik görüşüne göre butlan görüşünden farklı olarak tarafların geçersizliği ileri sürmeleri defi nileliğgindedir ${ }^{10 r}$.

* Gauch/Schiuel/Jäggi, N.558 vd.; Merz, Vertrag. 211 vd.; Merz., N.475 vd.; Schönenberger/Jäggi. Art.1l N.73; Ayrıntılı bilgi ve tartışma için bk\%.Altaş. 1.34 vd.. Kocayuslpaşikğ̣lu, 249-250.

"von Büren. 146-147: Schönenberger/Jäggi, Art.11. N.80: Altaş 140.

${ }^{\text {ton' }}$ Altaş, 142 ve aynı yer dn.354'te sayılan yazarlar.

${ }^{101}$ Altaş. 142 ve aynı yer dn. 356 'da suylian yazarlar. 


\section{c. Göriuşüntiz}

Butlan görüşünün uygulanması zaman zaman hakkaniyete uygun olmayan sonuçlar doğuımuştur. Bu nedenle şekle aykırılıktan dolayı geçersiz olan sözleşmelerin şartları varsa ayakta tutmak gereği ortaya çıkmıştır ${ }^{102}$.

Kanaatimizce, ilk olarak belirtilmesi gereken husus kefilin kefalet sözleşmesinin şekle aykırı olarak kurulduğunu öğrenmesi halinde alacaklıya ödemede bulunmasının normal bir yol olmamasıdır. Zira alacaklı genellikle tanınmayan bir kişi veya bir ticaret şirketidir. Geçersizlik bilindiği halde kefilin hangi sebeple alacaklıya ödeme yaptığı bilinmelidir. Bunun dışında çoğu zaman ödeme güçliugü içinde bulunan ve zaten bu nedenle de kefalet talebinde bulunmuş olan asıl borçluya rucu hakkını kullanma ihtimaline givenerek böyle bir ödeme yapması da makul görüinmemektedir.

Birinci ihtimalde kefilin geçersizliği bildiği halde alacakltya ödemede bulunması gerçekten bir bağışlama mahiyetinde olabilir. Sırf sayğmlı̆̆ının zedelenmemesi veya kendisine duyulan güvenin boşa çımaması gibi moral değerlerle yapılan ödemenin niteliği ancak bağışlama olabilir.

Kefilin kefalet sözleşmesini yaptığı anda şekle aykırılığı bilmesi ya da daha sonra bu durumu öğrenmesi ve kefalet borcu muaccel olduğunda isteyerek ifada bulunması halinde kefalet sözleşmesinin. şartlarının bulunması halinde geçerli olması mümkiundür.

Kefilin geçersizliği bilmesine ve ifada bulunmaması gerektiğini bildiği halde ödeme yapması mümkündür. Böyle bir durumda ifadan sonra kefilin alacaklıya karşı $\mathrm{BK}$ m.62 nedeniyle sebepsiz zenginleşme iddia etmesi mümkün değildir. Kefilin alacaklıya iade talebiyle başvurması halinde alacaklının kefilin talebini reddetmesi şekil kurallarının amacının yerine getirilmesi ilkesine uygundur. Çünkü geçersizliği bilerek ve isteyerek yapılan ifa şeklin koruma amaçnın gerçekleştiğini göstermektedir. Ancak geçersizliğin alacaklı tarafından ileri sürülmesi hakkın kötiiye kullanılması oluşturmamaktadır ${ }^{103}$.

Bu durumun hangi hallerde ortaya çıkacağını incelemek gerekmektedir. Gerçekten bir çözüm teklifi bir sorunun bulunması halinde yapılmalıdır. Kefil, şekle aykırılığı bildiği halde bağışlama kastı olmaksızın alacaklıya ifada bulunmuş ve asıl borçluya rucu etmiş olabilir. Pratik açıdan olaym bu aşamasına kadar hukuki bir sorun çıkmaz. Çünkü kefil kefalet borcunu ödemekte alacaklı da bunu almaktadır. Alacaklinm kefalet borcunun ödenmesine itiraz etmesi söz konusu olmayacaktır. Şu halde hukuki sorun kefilin asıl borçluya rucu etmesi halinde ortaya çıkacaktır. Kefil alacaklıya bağışlama kastı ile ödeme yapmışsa zaten rucu hakkını kullanmayacaktır.

\footnotetext{
102. Federal Mahkeme bir kararında sözleşmeye "geçerli imiş gibi" davranılacağı̆nı ifade etmektedir (BGE $98 \mathrm{Il} 316$ E.2).

${ }^{16983}$ kars. Muiller, 81 .
} 
Kefil asıl borçluya rucu ettiğinde iki ihtimal söz konusu olacaktır. İlkine göre asıl borçlu rucu için kendisine başvuran kefili tatmin edecektir. Bu ihtimalde yine herhangi bir sorun çıkmayacaktır. İkincisinde, asıl borçlu kefile ömeğin sorumluluk miktarının belirli olmamasına dayanılarak kefalet sözleşmesinin şekle aykırılık nedeniyle geçersiz olduğunu bunun butlan sonucunu doğuracağını, bu nedenle de kendisinin rucu borçlusu olmayacağını iddia edecektir. Bu iddia şekil şartının koruma amacının gerçekleşmesi ve asıl borçlunun itiraz hakkını kötüye kullanmasıı şartlarının birlikte gerçekleşmesi halinde reddedilir.

\section{aa. Şekil Şartının Amacının Gerçekleşmesi}

Bir sözleşmenin tarafı şekle aykırı surette kurduğu sözleşmeyi daha sonra bilerek ve isteyerek ifa etmişse başlangıçtan itibaren geçerli olan bir sözleşme söz konusu olur. Aynı şekilde bilerek ve isteyerek ifa etmemiş bulunan taraf, geçersizliği bilseydi dahi ifada bulunacak idi ise yine baştan itibaren geçerli bir sözleşmenin varlığı ileri sürülebilir. Nitekim şekil kurallarının amacının yerine gelmiş olması ile geçersizlik sonucunun kaldırılması sadece sırf tarafları koruma amacı taşıyan şekil kuralları için kabul edilebilir ${ }^{104}$. Bu sonuca varmak için katılaşmış şekil kuralları yerine bu kuralların şekil hükümlerini anlamsız ve yararsız kılmayacak surette yumuşatılarak uygulanması gerekmektedir ${ }^{105}$.

O halde kefil sırf kendisini koruyan şekil nedeniyle geçersiz sayılan kefaleti ifa etmişse, şeklin korumasından vazgeçmiş sayılır ${ }^{106}$. Zira durumu bilerek ödeme yapmışıır. Kaldı ki şekil kuralı amacına ulaşmış kefili korumuştur. Nitekim kefilin bu korumadan yararlanmak isteseydi ifada bulunmayacă̆ı söylenebilir.

Şekil hükümlerinin koruma amacının şekil şartına uymak dışında bir yolla gerçekleştiği hallerde geçersizliği ileri sürmek mümkün değildir ${ }^{107}$. Zira korunmak istenen sadece kefildir.

\section{bb. Hakkın Kötuiye Kullanılması Yasağ 1}

Medeni Kanunun 2'nci maddesinde dïzenlenen hakkın kötüye kullanılması yasağı hakim tarafından kendiliğinden dikkate alınacak kurallardandır. Tarafların ileri sürmesi zorunlu ve gerekli değildirin ${ }^{108}$.

\footnotetext{
${ }^{104}$ Altaş, 155 ve aynı yer 428 'de bulunan yazarlar.

${ }^{405}$ Müller, 81 .

${ }^{140}$ Federal Mahkeme bir kararında sözleşmenin şekle aykırı olarak yapıldığını bildikleri halde isteyerek ifada bulunan taraflardan birinin şekle aykırılı̆ga dayanmasını hakkin kötüye kullanılmast olarak değerlendimiştir (BGE I I 2 [l 333 E.2a).

"107 Furter, $116-117$.

109 Y İBK 30.09.1998 2/2.
} 
Hakkın kötüye kullanılması halinde şekil kurallarına uyulmamasına rağmen şartları varsa işlemin geçerli olması imkanı bulunmaktadır ${ }^{104}$. Şekil kuralarına aykırılık nedeniyle meydana gelen geçersizliği ileri sürme hakkı açıkça kötüye kullanılırsa bu hak kötüye kullanılmış olur ${ }^{\text {to }}$. Şekle aykırılık nedeniyle geçersiz bulunan sözleşmenin istenerek ifa edilmesi halinde kefilin asıl borçluya rucu etmesine karşılık asıl borçlunun geçersizlik iddiası hakkın kötïye kullanılmasını oluşturabilir. Ancak bazı ek şartların da bulunması gereklidir" ${ }^{\prime \prime}$.

Kefalet sözleşmesinde izah edildiği üzere bir sözleşmenin şekle aykırılık nedeniyle geçersizliğinin ileri sürülmesinin hakkın kötüye kullanılması olarak değerlendirip değerlendirilemeyeceği, donmuş ve genel olan kurallara göre değil, somut olayın bütün özellikleri dikkate alınarak belirlenir ${ }^{12}$.

Somut olay bakımından, kefílin sözleşmenin geçersizliğine rağmen alacaklıya ifada bulunması ve daha sonra asıl borçluya rucu etmesi halinde asıl borçlunun geçersizliği ileri sürmesi hakkın kötüye kullanılması teşkil eder. Zira, kefalette şekil sadece kefili korumak için öngörülmüştür. Assll borçluyu korumak gibi bir fonksiyonu bulunmamaktadır. Buna rağmen asıl borçlunun şekle aykırılığa dayanması hakkın kötüye kullanılması olarak deģerlendirilir. Özellikle kefalet sözleşmesinin, uygulamada sıkça görüldü̈gü gibi alacaklı ile asıl borçlu arasında hazırlandığı, kefilin ise sadece imza atmakla yetindiği, çoğu zaman kefalet senedini okumadığı gibi haller düşünüldügüünde, geçersizliğini ileri sürmesi haksız sonuçlara yol açabilecek niteliktedir. Asıl borçlunun geçersizlik itirazı kabul edildiģinde kefil şekle aykırılığı bilerek ödemede bulunduğu için Bk m.62 hükümlerine göre alacaklıdan sebepsiz zenginleşme talebinde bulunamayacak ve kefalet sözleşmesinin yapılmasında hiç bir yararı bulunmadığı halde zarar görecektir. Buna karşılık asıl borçlu sebepsiz zenginleşecektir. Çünkü alacaklı artik kendisinden asıl borcun ifasını isteyemeyecek, kefil ise geçersizlik itirazını aşamayacağından kendisine bir talepte bulunamayacaktır. Bu durum maddi adalete uygun bir sonuç değildir. Ayrıca asıl borçlu bu durumu yaratarak kefile yukarıda izah edildiği üzere zarar vermektedir.

Bunun dışında asıl borçlu şekle aykırılığa dayanarak borçlunun rưcu hakkını engelleyemez. Zira böyle bir durumda şekle aykırılık iddiası amaca uygun değildir ${ }^{113}$.

\footnotetext{
${ }^{1179}$ Müller, 81.

110 BGE 104 II 101 E.2.

"' BGE 112 II 333 E.2a.

112 von Tuls/Peter, 238; Y IBK 03.11.1980 3/2; BGE 93 ll 104; BGE 104 II 101 E.3: BGE 106 Il I5I E.9; BGE 112 II 333 E.2.

11" bkz.BGE 112 II 336.
} 


\section{KAYNAKÇA}

ALTAŞ, Huseyin: Şekle Aykurılığın Olumsuz Sonuçlarının Diizeltilmesi, Ankara 1998

ANDEREG, Karl: Die Formerfordernisse im neuen Bürgschaftsrecht, Diss. Bern, 1943

ARAL Fahrettin: Borçlar Hukuku Özel Borç İlişkileri, B.5, Ankara 2003

BAŞPINAR, Veysel: Borç Sözleşmelerinin Kısmî Butlanı, Ankara 1998

BECK. E.: Das neue Bürgschaftsrecht, Zürich 1942

BECKER, H.: Obligationenrecht, II.Abteilung, Dje einzelnen Vertargsverhältnisse Art.184-551, Bern 1934

BILGE, Necip: Borçlar Hukuku Özel Borç Münasebetleri, Ankara 1971

BUCHER, Eugen: Obligationenrecht, Besonderer Teil, 3.Aufl.Zürich 1988

EREN, Fikret: Borçlar Hukuku Genel Hükümler, C.I. B.6, lstıınbul 1998, C.II, B.5, Istanbul 1999

FRANKO, Nisim: Kefalet, Türkiye Noterler Birliği Hukuk Dergisi, Ankara (40) $11,1983,15-30$

FREY, H.Ueli: Die Voraussetzungen der Bürgschaft unter dem Gesichtspunkt des Bürgenschutzes, Diss. Zürich 1943

FURRER, Frank: Heilung des Formmangels im Vertrag, Zürich 1992

GAUCH/SCHLUEP/JÄGGI: Schweizerisches Obligationenrecht, Allgemeiner Teil, Bd.I, 6.Auflage, Zürich 1995

GIAVONALİ, S: Kommentar zum Schweizeriscehen Privatrecht, Bd.VI, Obligationenrecht, 2.Abt. Die einzelnen Vertragsverhältnisse, 7.Teilband, Art.429-529 OR Bern 1978

GIGER, Hans: Rechtsfolgen norm-und sittenwidriger Verträge, Zürich 1989

GRASSINGER, G.Elçin: Borçlar Kanunu'na göre Kefilin Alacaklıya karşı Sahip olduğu Savunma İmkânları, İstanbul 1997

HATEMİ/SEROZAN/ARPACI: Borçlar Hukuku Özel Bölüm, İstanbul 1992

HONSELL/VOGT/VIEGAND: Kommentar zum Schweizerischen Privatrecht, Obligationenrecht I. Art. 1-529 OR, Basel und Frankfurt am Main, 2.Aufl.. 1996 (Kısaltılmışı: OR/Pestalozzi)

KOCAYUSUFPAŞAOĞLU, Necip: Borçar Hukuku Genel Hükümler. Istanbul 2001

KOLLER, Alfred: Vom Formmangel und seinen Folgen in: Der Grundstückkauf, St.Gallen 1989

LARENZ, Karl: Lehrbuch des Schuldrechts, Erster Band, Allgemeiner Teil. 14.Auf1. München 1987 
: Lehrbuch des Schuldrechts Band Il. Besonderer Teil 11. Auflage, München 1977 (Kısaltılmışı: Larenz, Besonderer)

LERCH, Emil/TUASON, Vicente: Die Bürgschaft im Schweizerischen Recht, Zürich 1936

MERZ, Hans: Artikel 2 ZGB (Seperatabzug aus dem Einleitungsband des Berner Kommentars, umfassend die Artikel 1-10 ZGB), Bern 1962

-...----: Vertrag und Vertragsschluss, Freiburg Schweiz 1988 (Kısaltilmışı: Merz, Vertrag)

MÜLLER, Peter: Die Heilung formwidriger Rehchsgeschäfte durch Erfüllung, Diss. Ruswil (Luzern) 1938

OĞUZMAN, Kemal: Şekil Noksanı Sebebiyle Butlan Dermeyanı Hakkının Suistimali, İstanbul Barosu Dergisi, C.XXIX, S.6, sh.249-258 (Kısaltılmışı: Oğuzman, Suistimal)

OĞUZMAN, Kemal/M.Turgut ÖZ: Borçlar Hukuku Dersleri C.II, Istanbul 1971

OSER, H.: Das Obligationenrecht, Bundesgesetz betreffend die Ergänzung des schqeizerischen Zivilgesetzbuch vom 30.März 1911, Art.1-529, Zürih 1915

OSER/SCHÖNENBERGER: Das Obligationenrecht, Allgemeiner Teil (Art.1-183), 2.Aufl. Zürich 1929

REICHEL, Hans: Zum Bürgschaftsrecht VI, SJZ 20 (1923/24) 173-179

REIN, Walter: Die Voraussetzungen der Bürgschaft im Schweizeriscenrecht, Würzburg 1937

REISOĞLU, Seza Türk Hukukunda ve Bankacılık Uygulamasında Kefalet, Ankara 1992

-..--:- Kefalet Kavramı ve Muteberlik Şartları, AÜHFD, C.XIX, 1962, sh. 327-392 (Kısaltılmışı: Reisoğlu, Muteberlik)

Kefilin Rücuu, Ankara 1962 (Kısaltılmışı: Reisoğlu Rücu)

SCHWENZER, Ingeborg: Schweizerisches Obligationenrecht, Allgemeiner Teil, Bern 1998

SEROZAN/ARPACl/HATEMI: Borçlar Hukuku, Özel Bölüm, İstanbul 1992

SCHÖNENBERGER, W.JäGGİ, P.: Das Obligationemrecht, Kommentar zur 1. und 2. Abteilung (Art.1-529), Band V 1a, 1.Lieferung, Zürich 1973

TAHİROĞLU, Bülent: Roma Hukukunda Borcun Teminatlarından Kefalet, İHFM, XLII (1977), S.1-4, 323-340

TANDOĞAN, Haluk: Borçlar Hukuku Özel Borç İlişkileri C2, B.2 Ankara 1982 
TANDOĞAN, Haluk: Kefaletin geçerlilik şartları, BATİDER, IX (1977), S.1, 19-54 (Tandoğan, Geçerlilik)

TEKINAY, S.S: Kefalette muayyen miktar iraesi meselesi, İBD, 31, $15.09 .1958 .280-286$

TEKINAY, S.S: Müteselsil Borç ile Kefalet Arasında bir Mukayese, Adalet Dergisi 47 (1956) S.7, 742-752 (Kısaltılmışı: Tekinay, Müteselsil)

TOBLER, H: Der Schutz des Bürgen gegenuiber dem Gläubiger, Bern 1926 TUĞ, Adnan: Türk Özel Hukukunda Şekil, B.2, Konya 1994.

von BÜREN,: Schweizerisches Obligationenrecht, Allgemeiner Teil, Zürich 1964

von TUHR, A.: Bemerkungen zum Bürgschaftsrecht, SJZ 19 (1923), 225229 (veya 225 ff.)

: Bemerkungen zum Bürgschaftsrecht, SJZ 19 (1922/23), 245-249 (Kısaltılmışı: von Tuhr, Schluss)

von TUHR/PETER: Allgemeiner Teil des schweizerischen Obligationenrechts, Band I, 3. Auflage, Zürich 1979

WACKE, Andreas: Zwei Probleme aus Formmängeln schweizerischer Bürgschaftserklärungen, SJZ 74 (1978), $17 \mathrm{ff}$.

YAVUZ, Cevdet: Türk Borçlar Hukuku, Özel Hükümler, B.6, Ỉstanbul 2002 